\title{
O CAMPO DA FORMAÇÃO DOCENTE NO BRASIL: ANÁLISE DA PRODUÇÃO CIENTÍFICA (2008-2015)
}

\author{
Daniela Sene ${ }^{1}$ \\ Jane Kelly Oliveira Friestino ${ }^{2}$
}

\begin{abstract}
RESUMO: Trata-se de um estudo bibliográfico que objetiva analisar artigos publicados em um periódico indicado como de alto impacto na área de Educação no Brasil, sobre formação docente no país. Foram analisados 21 trabalhos publicados no período compreendido entre 2008 e 2015, utilizando para isto o método de análise de conteúdo proposta por Bardin (2009). Quatro categorias emergiram a partir das análises, sendo elas: políticas públicas para a formação docente; o currículo da formação docente; experiências de formação docente e formação e constituição da identidade profissional. Verificou-se maior ênfase nas propostas de formação continuada, uma aposta na valorização dos saberes docentes, bem como a cobrança de políticas públicas específicas para a formação docente nas diferentes esferas de atuação.
\end{abstract}

Palavras-chave: Formação de professores. Políticas públicas. Análise de conteúdo. Produção científica.

\section{THE FIELD OF TEACHER TRAINING IN BRAZIL: A SCIENTIFIC PRODUCTION ANALYIS BETWEEN 2008 AND 2015}

ABSTRACT: It is a bibliography study that aims to analyse articles published in a journal indicated as having a high impact in the area of Education in Brazil, about teacher training in this country. We analyzed 21 papers published between 2008 and 2015, using the content analysis method by Bardin (2009). Four categories emerged from the analyzes, such as: public policies for teacher training; the

\footnotetext{
${ }^{1}$ Mestre em Psicologia e Educação pela USP. Supervisora Escolar - Secretaria Municipal de Educação. Prefeitura de São Paulo. São Paulo-SP/Brasil. E-mail: daniellasene@gmail.com

${ }^{2}$ Doutora em Saúde Coletiva. Universidade Federal da Fronteira Sul - UFFS campus Chapecó e UAB/UNIFESP. Chapecó-SC/Brasil. E-mail: jane.friestino@uffs.edu.br
} 
curriculum of teacher education; experiences of formation and formation and constitution of the professional identity. There was a greater emphasis on the proposals for continuing training, a focus on the valuation of teaching knowledge, as well as a charging of specific public policies for teacher training in the different spheres of activity.

Keywords: Teacher training. Public policies. Content analysis. Scientific production.

\title{
EL CAMPO DE LA FORMACIÓN DOCENTE EN BRASIL: UN ANÁLISIS DE LA PRODUCCIÓN CIENTÍFICA ENTRE 2008 Y 2015
}

\begin{abstract}
RESUMEN: Se trata de un estudio bibliográfico que objetiva analizar artículos publicados en un periódico indicado como de alto impacto en el área de Educación en Brasil, sobre formación docente en el país. Se analizaron 21 trabajos publicados en el período comprendido entre 2008 y 2015, utilisando el método de análisis de contenido propuesto por Bardin (2009). Cuatro categorías surgieron a partir de los análisis, siendo ellas: políticas públicas para la formación docente; el currículo de la formación docente; experiencias de formación y formación y constitución de la identidad profesional. Se verificó un énfasis más acentuado en las propuestas de formación continua, una apuesta por la valorización de los saberes docentes, así como un cobro de políticas públicas específicas para una formación docente en las diferentes esferas de actuación.
\end{abstract}

Palabras clave: Formación de profesores. Políticas públicas. Análisis de contenido. Producción científica.

\section{Introdução}

A formação docente constitui-se em tema polêmico na atualidade e apresenta-se nos diversos documentos legais e produções acadêmicas como um dos fatores estratégicos para a melhoria da educação e ampliação das perspectivas sobre a profissão. A literatura sobre a formação docente tem utilizado os conceitos formação inicial (antes do ingresso na profissão docente), continuada (como atualização profissional) e inicial ou continuada em serviço (quando o professor ou professora obtém a formação exigida para sua atuação, mas já está em exercício) para discorrer sobre as diferentes modalidades formativas.

De acordo com Bello (2014), a história recente da formação docente no Brasil pode ser 
dividida em dois momentos. O primeiro, com início nos anos 1990 até 2008, é caracterizado por ações do governo federal de caráter regulador e promotor de ações de formação em serviço em massa, em que estados e municípios em associação com universidades públicas ofereceram formação superior, em curto espaço de tempo, valendo-se das tecnologias e de materiais padronizados. O segundo momento, a partir de 2009, caracteriza-se pela instituição da Política Nacional de Formação de Profissionais do Magistério da Educação Básica (BRASIL, 2009), quando o controle do Estado sobre esta formação se torna oficial e, portanto, mais abrangente, atribuindo um novo papel à Coordenação de Aperfeiçoamento de Pessoal de Nível Superior (CAPES), que contribuiu com a construção da Universidade Aberta do Brasil e a Plataforma Paulo Freire, por exemplo.

Um estudo realizado por Sene (2010), no período entre 1997 a 2007, durante a chamada Década da Educação, tendo como lócus de análise o periódico Cadernos de Pesquisa, identificou formações discursivas de diversos agentes do campo educacional (pesquisadores, organismos internacionais, burocracia estatal, professores), revelando o desejo de mudança. Os índices de qualidade da educação brasileira e da formação docente como um todo, nesse período, geravam apostas e disputas entre os diversos grupos de agentes envolvidos, por exemplo, sobre como (currículo, duração, metodologia), onde (academia, institutos de educação, escolas) e quando (antes ou após o ingresso na profissão) devereria se investir, para que a formação docente impactasse diretamente na qualidade da educação básica no país.

Em contrapartida, na produção científica desse mesmo período e revista ocorreram idiossincrasias, dilemas e conflitos vividos pelos professores no cotidiano profissional e nos cursos de formação inicial, continuada, em serviço, ampliando as perspectivas sobre a profissão e formação docentes (SENE, 2010). A partir dos achados anteriores, temos interesse particular em analisar o conteúdo dos artigos publicados sobre formação de professores neste segundo período, chamado pós Década da Educação (2008 a 2015), em um periódico indicado como de alto impacto na área de Educação no Brasil.

\section{Método}


Trata-se de uma análise bibliográfica tendo como objeto o periódico Cadernos de Pesquisa, a partir do mesmo referencial teórico-metodológico descrito por Sene (2010), com vistas a mapear os discursos e debates produzidos; rupturas, continuidades e novidades em relação à análise encontrada na literatura, dada a relevância atribuída à formação de professores ainda nos dias de hoje. Foram realizadas buscas no banco de dados do portal Scielo, local em que o periódico encontra-se indexado, em publicações no período de 2008 a 2015, utilizando-se os descritores "formação de professores", seguidas da leitura dos resumos para avaliar a pertinência da inclusão dos artigos na análise. Foram excluídos os artigos que discorriam sobre a formação de professores em outros países ou que apresentavam pesquisas históricas anteriores ao ano de 2008.

\section{A Escolha do Periódico}

O periódico Cadernos de Pesquisa, em atividade desde julho de 1971, foi avaliado no Qualis-Periódico como A1 no quadriênio 2013-2016 pela CAPES, na área de Educação e justifica-se por ter sido analisado por Sene (2010), sob a mesma perspectiva ao qual se objetiva neste estudo. Além disso, o estudo de André et al. (1999), em 10 periódicos expressivos e acessíveis em circulação no Brasil, já indicava a relevância desse periódico neste tema. No período de 1990 a 1997, o Cadernos de Pesquisa apresentou 24 artigos sobre o tema da formação de professores, ou seja, 21\% dos 115 artigos de periódicos analisados no período. Assim, o periódico se configura como meio privilegiado para a manifestação dos discursos sobre a formação de professores. Tendo como locus de estudo o periódico, Cadernos de Pesquisa, recorreu-se a Bourdieu (1983, 2004), pois os discursos (ou formações discursivas) nascem de outros discursos e a eles são reenviados, e isto se desenrola no que poderíamos chamar de campo - espaços estruturados de posicionamentos sobre determinada matéria, definidos pela presença de disputas e de interesses específicos de quem pertence a ele e foi formado para nele estar e intervir.

As políticas públicas pós Lei de Diretrizes e Bases da Educação Nacional (LDB) (BRASIL, 1996), num primeiro período (1997-2007), por exemplo, focalizaram principalmente as professoras na Educação Infantil e anos iniciais do Ensino Fundamental, grupo majoritário sem 
a formação mínima para o magistério (SENE, 2010). Após um intenso debate sobre a legitimidade da Educação a Distância (EAD), no início dos anos 2000, esta se consolida como modalidade oficial para a formação inicial e capacitação de docentes em exercício. A criação de novos programas e cursos de formação, como os Institutos Superiores de Educação (ISEs) e o Curso Normal Superior, aliados às Novas Tecnologias da Educação e da Comunicação, surgem como alternativa histórica heterodoxa para a ampliação da oferta de ensino superior. Essas inovações causam ampla movimentação discursiva e dividiram opiniões a respeito de sua legitimidade no campo da formação docente (ANDRÉ, et. al. 1999; ANDRADE, 2007; BELLO, 2008, SENE, 2010).

Diante do exposto, foi problematizada anteriormente a existência de um campo específico dentro do campo educacional - o campo da formação de professores - com disputas pela forma, conteúdo, duração e lócus para a promoção da formação de professores no país. Nosso estudo se insere nesse contexto com uma análise de conteúdo dessas formações discursivas, emitidas por diversos agentes nesse campo, ocupando posições mais ou menos ortodoxas, manifestadas nas publicações do periódico em questão.

\section{Dispositivos de Análise}

Como dispositivo analítico utilizou-se a análise de conteúdo proposta por Bardin (2009), que trata da utilização de procedimentos sistemáticos e objetivos que permitem a inferência de conhecimentos relativos às condições de produção e recepção de mensagens produzidas. Enquanto método, realiza agrupamento de elementos importantes com características comuns, resultando em categorias que possibilitam uma discussão junto ao conhecimento prévio descrito pela literatura. Para sua execução, foram seguidas as etapas: 1) a pré-análise, com realização de leitura flutuante; 2) a exploração do material, com leitura exaustiva dos achados e; 3) o tratamento dos resultados: a inferência e a interpretação, ou seja, a categorização.

A partir do descritor "formação de professores" foram encontrados 24 artigos, e após a realização da pré-análise e exploração do material, 3 artigos foram excluídos por não tratarem diretamente da formação de professores no contexto brasileiro, totalizando ao final 
21 trabalhos. Após a leitura exaustiva e por meio da inferência e interpretação, quatro categorias emergiram a partir das análises, sendo elas: políticas públicas para a formação docente; currículo de formação; experiências de formação docente e formação e constituição da identidade profissional.

\section{Contextualização dos Achados (2008 a 2015)}

No período que compreende o início de 2008 a dezembro de 2015 foram analisados 21 artigos, nos quais os colaboradores neste período possuíam vínculos com instituições de pesquisas brasileiras e problematizavam nossa realidade, diferentemente do período analisado por Sene (2010), em que houve 7 artigos assinados por colaboradores de diversos países, retratando diferentes cenários. Percebe-se que desses 21, 12 artigos discorreram sobre a formação docente de forma ampla; 04 problematizaram a formação de docentes especialistas (cuja atuação restringe-se aos anos finais do ensino fundamental e médio); 3 artigos abordaram a formação de docentes dos anos iniciais do ensino fundamental e, por fim, 02 artigos debruçaram-se nas questões da formação de docentes para a educação profissional.

O ano que possui o maior número de publicações é 2012, com 6 artigos, seguido pelos anos 2009 e 2015 com 4 estudos cada, 2011 com 3 e 2008, 2011, 2013 e 2014, com apenas 1 trabalho por ano. Na análise temática realizada por Sene (2010), entre 1997 e 2007, foram relatados 43 artigos sobre o tema, e os "picos de publicação" corresponderam aos anos de 1997, 2000 e 2005, com 5 em cada ano e, o ano de maior publicação foi 2007, com 8 trabalhos ao todo, conforme observa-se na Figura 1.

A média de 4,3 publicações por ano, entre 1997 e 2007, passa para 3,0 no período subsequente. A ampla produção discursiva no primeiro período pode ser efeito da promulgação da Lei de Diretrizes da Educação (Lei 9394/96). Entre 1988 e 1996, por exemplo, não houve mais de 3 publicações por ano sobre esse tema (SENE, 2010).

Com o estabelecimento da obrigatoriedade da formação em nível superior para a atuação na educação infantil e nos anos iniciais do ensino fundamental, dentre outras normatizações trazidas por esta nova LDB (BRASIL, 1996), instituindo a chamada Década da 
Educação (1997 a 2007), esperava-se que, ao final deste período, o Brasil tivesse avançado em diversos aspectos relacionados à melhoria da qualidade da educação básica. Nessa aposta, o nível e qualidade da formação docente foram considerados fatores estratégicos.

Assim, entre 1997 e 2007, tal como na pesquisa de André et al. (1999), a análise realizada por Sene (2010) indicou que os discursos incidiam, prioritariamente, sobre as professoras de educação infantil e anos iniciais do ensino fundamental, que, historicamente, possuíam menor formação profissional, representado em 18 artigos (41,8\%) dos estudos analisados. No entanto, o debate não se encerra com o término da Década da Educação. Os achados para o período de 2008 a 2015 evidenciam um cenário diferente, demonstrando uma abordagem dada à educação infantil somente em 3 artigos (14,2\%). Percebe-se uma mudança no foco de análise das publicações: a formação de docentes da educação infantil e anos iniciais do ensino fundamental deixa de ser enfatizada de forma tão exclusiva e enfática, conforme evidencia a Figura 1.

Figura 1 - Número absoluto de publicações de acordo com as modalidades de atuação docente encontradas no periódico Cadernos de Pesquisa no período de 1997 a 2015.

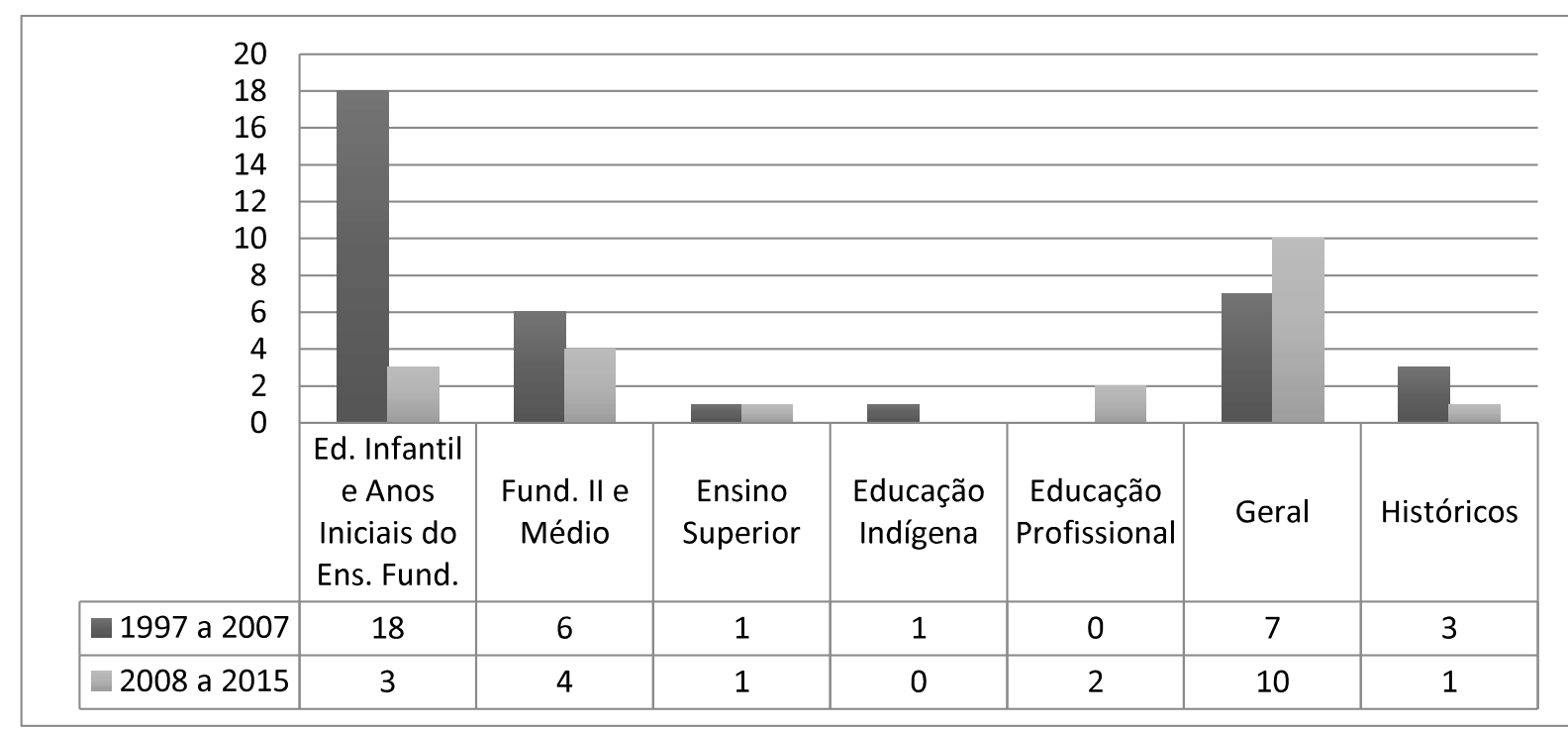

Fonte: Levantamento de dados na revista Cadernos de Pesquisa da Fundação Carlos Chagas de 2008 a 2015 e SENE (2010).

Porém, o fato de não haver mais tanta ênfase na formação dos profissionais para a educação infantil e anos iniciais, pode ser por se tratar de um período posterior a um grande 
investimento das políticas públicas para a formação destes que resultou na "diplomação" ou "certificação" de milhares de professores no país, pelos chamados Programas Especiais de Formação Pedagógica Superior, também chamados de PECs, com validação da experiência docente (ANDRADE, 2007; BELLO, 2008; SENE, 2010).

Contudo, as publicações sobre a formação de docentes especialistas, para atuação na segunda etapa do ensino fundamental e médio, mantiveram-se no mesmo ritmo. Verifica-se a partir desses indícios que o foco dos discursos passa a ser nos docentes da educação básica como um todo.

Outro achado refere-se ao silêncio discursivo com relação à formação docente para a educação técnica-profissional entre 1997 e 2007 (SENE, 2010). No entanto, na recente análise, foram encontrados 2 artigos (FARTES; SANTOS, 2011; GARIGLIO; BURNIER, 2014).

Nessa mesma perspectiva, a discussão sobre a formação dos docentes para o ensino superior e indígena contou com apenas 1 artigo cada, no período que se estende entre 1997 e 2015. Essa baixa expressividade discursiva merece uma pesquisa aprofundada para compreensão dos movimentos nesses campos específicos, bem como em outros, também não mencionados, como formação de docentes para a educação especial, comunidades quilombolas, ribeirinhas, dentre outros. Além dessas constatações iniciais, a construção da análise permitiu a comparação dos artigos, identificação de tendências, propostas e disputas em torno de como, onde e quando devem acontecer as ações, programas e políticas voltadas à formação docente na atualidade de forma mais aprofundada.

Os artigos pesquisados foram categorizados em quatro grupos, sendo que um mesmo trabalho pôde ser incluído em mais de uma categoria, sendo elas: 1) Políticas públicas para a formação docente (11 artigos); 2) O currículo da formação (5 artigos); 3) Experiências de formação docente (7 artigos) e 4) Formação e constituição da identidade profissional (5 artigos), conforme consta no Apêndice 1. A Figura 2 ilustra a quantidade e proporção de publicações agrupadas nessas quatro categorias, revelando também uma tendência no enfoque dos autores nas experiências de formação para a discussão e proposição de políticas públicas neste campo. 
Figura 2 - Proporção de publicações do Cadernos de Pesquisa de acordo com as categorias analisadas* no período de 2008 a 2015.

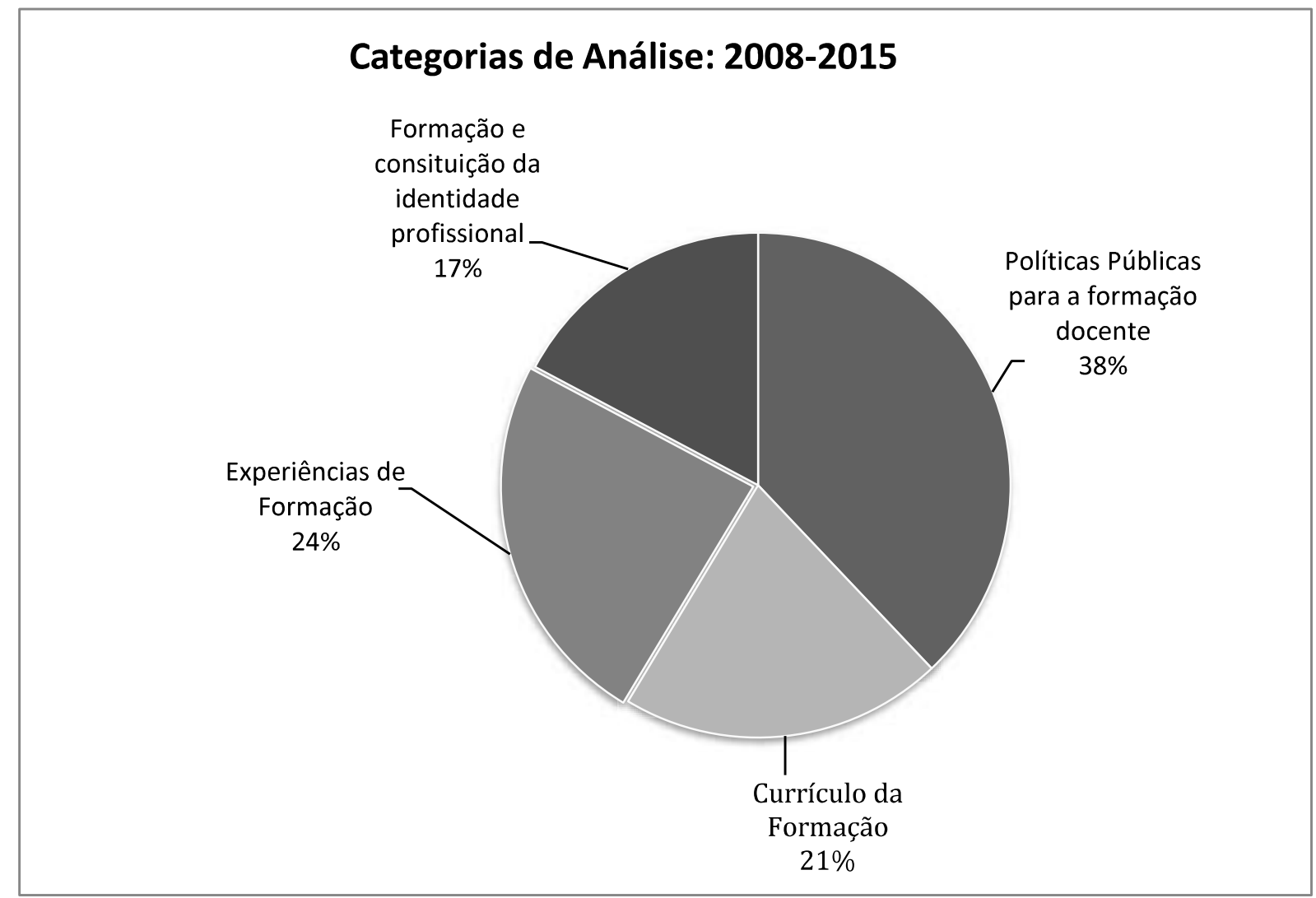

Fonte: Levantamento de dados na revista Cadernos de Pesquisa da Fundação Carlos Chagas de 2008 a 2015.

*Alguns artigos foram classificados em mais de uma categoria de análise.

\section{Políticas Públicas para a Formação Docente}

Nesta categoria verificou-se a publicação de 10 artigos que se dispuseram a discutir e propor Políticas Públicas para a Formação docente, em âmbito federal, estadual ou municipal (SCHEIBE, 2011; DAVIS et. al., 2011; FARTES; SANTOS, 2011; BARRETTO, 2012; PLACCO; SOUZA; ALMEIDA, 2012; SOUSA; BÔAS, 2012; GARCIA; BIZZO, 2013; GARIGLIO; BURNIER, 2014; BENITES; SARTI; SOUZA NETO, 2015; LOPES; BORGES, 2015). Ao analisar o papel do Conselho Técnico-Científico da Educação Básica da Capes na formulação de políticas e no desenvolvimento de atividades de suporte à formação dos profissionais do magistério (inicial 
e continuada), Scheibe (2011) pontua dificuldades tanto com relação à formação inicial quanto à continuada no país, devido à fragmentação das políticas públicas, ao rebaixamento das exigências de formação, rapidez da formação e recursos insuficientes. Esse contexto estaria contribuindo mais para uma "desprofissionalização dos docentes" do que seu inverso.

\begin{abstract}
Nesse mesmo quadro, as condições educacionais bastante abaixo dos padrões atingidos por outros países em patamares semelhantes de desenvolvimento econômico ao do Brasil impuseram a adoção de providências emergenciais, especialmente a formação inicial em serviço e a formação continuada dos profissionais do magistério, consideradas agendas indiscutíveis nas políticas educacionais (SCHEIBE, 2011, p. 815, grifos nossos).
\end{abstract}

Nesse sentido, reafirma o papel primordial das universidades na formação inicial e das possibilidades virtuais para a continuada, defendendo a importância de um Programa Nacional de Formação para Professores da Educação Básica. No entanto, enquanto essa política não se concretiza, não se descarta a necessidade da adoção de "programas emergenciais" de complementação pedagógica e licenciaturas em serviço.

Acerca da formação inicial, Benites, Sarti e Souza Neto (2015) trazem uma inquietação sobre a forma como o estágio supervisionado nas licenciaturas tem se concretizado, como "mera complementação da formação acadêmica, perdendo sua especificidade como oportunidade de aproximação do trabalho docente e espaço de iniciação à docência", caracterizando-se por certa espontaneidade e improvisação. Reivindicam, portanto, uma regulamentação legal mais específica para o estágio supervisionado, bem como a necessidade de se implementar uma verdadeira articulação entre universidade e escola, promovendo o desenvolvimento de saberes teóricos a partir das práticas.

A discussão sobre a potencialidade do estágio supervisionado só havia aparecido antes com Gomes e Pereira (2009). Em seu artigo, problematizaram a importância do estágio supervisionado para a formação docente e o descaso das políticas que o regulamenta. No período anterior (1997 a 2007), não foi localizado nenhum artigo sobre o tema.

Já o estudo de Sousa e Bôas (2012) apresenta alguns dilemas em torno de como avaliar a qualidade da formação inicial e de docentes já em exercício. Discorre sobre as possibilidades 
e limitações do Exame Nacional de Desempenho de Estudantes (ENADE) - com o uso de provas padronizadas para avaliar a qualidade da formação inicial - e do uso das avaliações como o SAEB e a Prova Brasil para avaliar o desempenho de docentes em exercício. Por isso, propõe outra abordagem que não seja exclusivamente focada em aspectos cognitivos do professor ou de seus alunos, dado que a sua profissionalidade se manifesta em contexto, a partir dos diversos saberes desenvolvidos (disciplinares, atitudinais e experienciais).

Fartes e Santos (2011) afirmam que a educação profissional e tecnológica pós LDB (1996) vai além da ideia de ensino profissionalizante. Abrange ensino médio técnico, graduação (tecnólogo) e pós-graduação. Criticam as políticas de formação com o propósito de complementar a formação inicial dos docentes não licenciados, que desconsideram os saberes oriundos da experiência, reivindicando uma formação específica que lhes permita articular o mundo do trabalho e a educação profissional, na constituição de corpus de saberes.

Por fim, a pesquisa qualitativa de Davis et al. (2011) fornece um panorama das políticas de formação continuada realizadas em diferentes estados e municípios. Concluem que ela não é vista pela maioria dos gestores educacionais como correção da formação inicial, mas como atualização dos conhecimentos e habilidades para o aprimoramento da profissão. Essa tensão entre o lugar, relevância e legitimidade da formação continuada (ou em serviço) como correção ou complementação da formação inicial em contraposição à sua oferta como direito ao desenvolvimento e atualização profissional não está tão presente, como no período anterior (SENE, 2010).

Em síntese, as proposições de políticas públicas para a formação docente no período apostaram na formação continuada como estratégia para a melhoria da educação básica, uma vez que no período anterior houve amplo movimento político-estatal para a formação inicial em massa dos professores de educação infantil e anos iniciais do ensino fundamental. Nesse período, também observamos a reivindicação de atenção para a formação do professor que atua na educação profissional, a partir das especificidades desta modalidade, bem como um investimento discursivo numa outra concepção de estágio supervisionado durante a formação inicial do professor, para a melhoria da qualidade da educação no país. 


\section{o Currículo da Formação Docente}

A respeito do currículo da formação inicial, pode-se verificar a proposição de abordagens voltadas para uma formação multi/intercultural, inclusiva, que considere a diversidade cultural, étnica, social, envolvendo questões de gênero, sexualidade, raça/etnia, com um total de 6 artigos (SENNA, 2008; GOMES; PEREIRA, 2009; ROHDEN, 2009; LÜDKE; BOING, 2012; MENDONÇA; SILVA, 2015; LOPES; BORGES, 2015).

Senna (2008) propõe resgatar o ensino como especialidade acadêmica a partir da reflexão sobre o currículo das licenciaturas. Em seu artigo, discute o fenômeno do fracasso escolar e a necessidade de a escola ser inclusiva, pois se percebe um estranhamento entre os novos sujeitos escolares (docentes e discentes). Faz crítica ao modelo de formação tecnicista e ao atual que não teria rompido com uma concepção de sujeito universal, bem como citam Gomes e Pereira (2009), em face dos desafios das "violências das e nas escolas". Assim, contextos de educação intercultural deveriam ser primazia na formação docente, de acordo com esses agentes do campo.

\footnotetext{
E entre discussões sobre o tempo mínimo de titulação, o regime de curso, a quantidade de horas de estágio, a solução de problemas quanto à adequação entre teoria e prática, enfim, sobre o modo de formação, passou ao largo a discussão essencial quanto ao saber que, objetivamente, o professor precisaria ter para se tornar agente de educação inclusiva (SENNA, 2008, p. 211).
}

Nessa mesma perspectiva, Rohden (2009), a partir de uma experiência piloto de formação continuada a distância, discorre sobre a necessidade de introduzir temáticas referentes à diversidade no currículo da formação. O trabalho de Mendonça e Silva (2015), a ser aprofundando na próxima seção, aposta na formação continuada e enfatiza a necessidade de a escola colaborar para construção de uma sociedade em que as diferenças identitárias e as deficiências não sejam vistas como desvantagens ou patologias, defendendo uma política de inclusão, uma vez que a exclusão consiste na negação da diversidade. Destaca ainda a importância das condições de trabalho desse profissional para a mudança educacional.

Temos observado que o professor está em processo de (re)significação 
permanente, vivenciando um embate histórico (portanto, dialético e contraditório) entre o discurso hegemônico das forças segregacionistas e a construção de novos significados das práticas inclusivas e inovadoras. Dessa forma, abrir questionamentos sobre a formação continuada de professores é fundamental (MENDONÇA; SILVA, 2015, p. 518).

Já Lüdke e Boing (2012) conduzem críticas diretas às faculdades de educação. Propõem que voltem-se para as práticas e saberes docentes, reconduzindo-os para a teorização. Citam a questão da socialização profissional retroativa ao tempo em que os professores eram alunos, como um fator a ser levado em consideração no currículo da formação docente. Acreditam que a universidade pode potencializar o desenvolvimento da profissionalidade docente por meio do realocamento do trabalho no centro da formação, pois ela seria capaz de fazer a ligação entre aspectos pré-profissionais e profissionais, produzindo conhecimentos sobre as práticas.

Por fim, Lopes e Borges (2015) questionam as políticas de currículo de formação docente voltadas a uma perspectiva de mudança social, a partir de um referencial pósestruturalista.

No registro que aqui defendemos, a noção de currículo como um conhecimento selecionado a partir de uma cultura mais ampla para ser ensinado a todos, em nome de um projeto de transformação social e de formação de sujeitos, é desestabilizada [...], tal como são desestabilizados os projetos curriculares que têm por propósito formar uma dada identidade no aluno ou operar com uma identidade profissional docente preestabelecida (LOPES; BORGES, 2015, p. 498).

Para as autoras, a formação docente é um projeto impossível, necessário e que precisa se perceber como imprevisível para poder avançar. Propõem a ousadia de se admitir os embates políticos entre as diferentes perspectivas de estabilização do discurso sobre a formação:

[...] tendências críticas articuladas a tendências instrumentais; enfoques multiculturais articulados a demandas profissionais; demandas profissionais que se vinculam a interesses institucionais e pessoais específicos e por aí vai, admitindo tensões e contradições que permeiam as propostas curriculares (LOPES; BORGES, 2015, p. 503). 
Assim, os trabalhos que discutem o currículo, o conteúdo dos cursos de formação de professores, sejam eles de formação inicial ou continuada expressam insatisfação, reivindicando um rompimento com abordagens que considerem alunos e professores sujeitos universais, que necessitam de saberes técnicos-instrumentais, apostando no potencial da diversidade humana, em uma perspectiva cultural e social da profissão, com ênfase na tematização de saberes e práticas docentes.

\section{Experiências de Formação Docente}

Neste eixo foram encontrados 7 artigos que, partindo da reflexão sobre experiências de formação, contribuíram com os discursos neste campo. Diferentemente do período anterior, em que foram localizados artigos discutindo especificamente a formação inicial, os 7 trabalhos discorrem sobre experiências de formação continuada ou contínua, de docentes em exercício (LOPONTE, 2009; REALI; TANCREDI; MIZUKAMI, 2010; DAVIS, 2011; BEINEKE, 2012; GARCIA; BIZZO, 2013; CHARRÉU; OLIVEIRA, 2015; MENDONÇA; SILVA, 2015).

Os artigos de Loponte (2009) e Beineke (2012) abordam principalmente as contribuições dos saberes docentes para a promoção de experiências de formação diferenciadas: a primeira, não-formal, desinstitucionalizada entre um grupo de amigas e a segunda, ao analisar o potencial da reflexão sobre a formação docente. Enfim, a amizade e a reflexão aparecem nesse contexto, respectivamente, como facilitadora da aprendizagem e como "dispositivo de formação", reiterando a centralidade do papel de um "outro" próximo, nesse processo de desenvolvimento profissional.

Em perspectiva semelhante, o trabalho de Mendonça e Silva (2015) defende uma metodologia de formação docente que favoreça a inclusão das pessoas com deficiência na escola e discorre brevemente sobre uma experiência junto a docentes do primeiro ao quinto ano do ensino fundamental de uma escola da rede pública de Brasília-DF. Aposta na formação continuada, com a problematização da prática docente a partir do conceito de "clínica da atividade". O artigo reivindica espaço e tempo, portanto condições de trabalho, para que o "meio associado", entendido no caso da educação como coletivo docente, possa por meio da linguagem fazer a coanálise de práticas para reorganizá-las e modificá-las (CLOT apud 
MENDONÇA; SILVA, 2015).

O principal recurso a ser utilizado seriam as gravações em vídeo, segundo Mendonça e Silva (2015), pois a atividade conjunta do sujeito com os outros é a mola propulsora de sua história, e o resultado seria um empoderamento do coletivo e a emancipação educacional, a depender da qualidade das intervenções do formador ou pesquisador, com o entendimento de que "todo o ser humano sabe uma diversidade de coisas e apresenta uma inteligência que não pode ser mensurada como superior ou inferior". As autoras criticam ainda a escassez de trabalhos acadêmicos que focalizem o diálogo com as práticas pedagógicas e a análise de situações reais de sala de aula, além do desencontro entre as demandas reais do professorado e os cursos de formação oferecidos pelas redes de ensino.

Já a pesquisa de Davis et al. (2011) acerca da formação continuada em diferentes estados e municípios nos fornece um panorama amplo e detalhado das iniciativas das diferentes Secretarias de Educação. O estudo revela que, na maioria das entrevistas, a formação continuada não aparece como correção da formação inicial, mas como atualização dos conhecimentos e habilidades para o aprimoramento da profissão. As autoras identificam perspectivas de formação continuada mais individualistas, focalizadas na figura docente, e outras colaborativas, tomando a escola e o coletivo docente como propulsores do aperfeiçoamento profissional.

Nas perspectivas mais individualistas, espera-se o desenvolvimento da ética e do conhecimento político, a superação dos déficits da formação inicial e o respeito ao ciclo de vida profissional. Com o objetivo de motivar os docentes a atualizar seus conhecimentos, por meio de oferecimento de cursos de curta duração, visando articulação entre teoria e prática, com o uso de oficinas, palestras, seminários, congressos e jornadas. Também foram encontradas experiências de formação continuada terceirizada, bem como menção ao uso dos programas de formação federais, como é o caso do Programa Gestar e Pró-Letramento. Já as abordagens colaborativas tendem a focalizar o Coordenador Pedagógico como principal responsável pelas ações de formação na escola, mas não o único - porque também pode possuir formação limitada e ter pouca autonomia - e a própria escola como lócus de formação contínua e permanente, ao incentivar a experimentação didática, produção de materiais, o 
uso de novas estratégias de ensino (DAVIS et al., 2011).

O relato sobre o desenvolvimento da pesquisa-ação realizada por Reali, Tancredi e Mizukami (2010) acerca de um programa de mentoria online dirigido a docentes dos anos iniciais do ensino fundamental com até cinco anos de experiência, permitiu às autoras conhecerem melhor as dificuldades enfrentadas pelas professoras iniciantes, colaborando bem com os artigos de Loponte (2009) e Beineke (2012), na proposição e discussão de novos modelos de formação em serviço. Embora o curso fosse a distância, o artigo defende a escola como lócus privilegiado para essa formação, uma vez que as questões do curso partiam de uma realidade concreta, valorizando os saberes advindos da experiência de um outro mentor, par avançado (REALI; TANCREDI; MIZUKAMI, 2010).

O estudo de caso analisado por Garcia e Bizzo (2013) sobre um programa de formação contínua para professores de Ciências, traz subsídios para o planejamento de novas atividades para a educação a distância de docentes em exercício. Identifica mecanismos de estudo, aprendizagem e dificuldades desse grupo, visando contribuir para a proposição de cursos mais atrativos e eficientes, para minimizar as desistências ao longo do processo. Nesse contexto, apresentam dados de 2010 em que 31,5\% dos cursos EaD oferecidos no Brasil eram voltados a docentes de acordo com a Associação Brasileira de Educação a Distância (ABED).

Uma das políticas mais eficazes do governo federal, nesse projeto de expansão, foi o lançamento do sistema UAB, que visa, entre outras coisas, democratizar, expandir e interiorizar a oferta de ensino superior público e gratuito no Brasil. A prioridade desse sistema é a formação de professores para a educação básica, com a integração entre instituições públicas de ensino superior de estados e municípios brasileiros (GARCIA; BIZZO, 2013, p. 999).

Os artigos de Garcia e Bizzo (2013) e Reali, Tancredi e Mizukami (2010), dentre outros, evidenciam que as chamadas Tecnologias da Informação e Comunicação, que foram diversas vezes mencionadas como novas TICS, deixam de ser vistas ou pensadas como novas, foram assimiladas pelos discursos e propostas do campo da formação, deixando de serem alvos de críticas severas, havendo uma maior aceitação desta modalidade na formação continuada (SCHEIBE, 2011). 
Por fim, o artigo de Charréu e Oliveira (2015) parte de um relato de prática que teve os diários de aula e portfólios como material para formação docente e avança para um estudo teórico destes recursos. Propõem que o uso dessa metodologia visa qualificar o trabalho do professor e possibilitar uma reflexão sobre a sua própria prática, o que, no entanto, também pode ser usado pelo seu formador, na universidade ou na escola.

Nessa categoria, pudemos perceber uma tematização da forma como o profissional professor aprende, a importância dos pares e coletivos educacionais como propulsores da aprendizagem. Percebemos a defesa de diversos dispositivos de formação como a "tematização de práticas", a partir de gravações, filmagens e de registros do professor (diários de aula e portfólios). Além disso, o surgimento de outros agentes formativos: como o tutor e o mentor, para além do coordenador pedagógico. Por fim, a continuidade dos cursos de EaD para professores.

\section{Formação e Constituição da Identidade Profissional}

Nesta última categoria foram incluídos os 5 trabalhos que discursaram sobre a constituição da identidade profissional docente, discorrendo sobre a importância da escola e dos colegas de profissão, bem como da proposição de políticas públicas para a profissionalização da profissão (GARCIA, 2009; GRIGOLI et al., 2010; PLACCO; SOUZA; ALMEIDA, 2012; BARRETO, 2012; LÜDKE; BOING, 2012; GARIGLIO; BURNIER, 2014; BENITES; SARTI; SOUZA NETO, 2015; CHARRÉU; OLIVEIRA, 2015). A pesquisa de Grigoli et al. (2010, p. 240) conclui que "a escola é o lugar que mais colabora para aprendizagem do professor". Destaca a importância da rede de relações que se estabelece no contexto da escola, como forma de socialização, construção da identidade e formação, defendendo a escola como lócus privilegiado para a formação continuada. Nesse contexto, reivindica o direito de a escola formar e, portanto, poder, mais status, no campo da formação (BOURDIEU, 2004).

Placco, Souza e Almeida (2012) se posicionam no campo reiterando o papel do coordenador pedagógico como responsável pela formação continuada docente na escola, além da função de articulador do Projeto Pedagógico e implementador das políticas educacionais. Para tanto, as autoras defendem a proposição de políticas voltadas para uma 
formação específica desse profissional, diferente da formação docente, garantindo a construção de sua identidade,

[...] como processo constitutivo do sujeito, produzido e construído nas interações com outras pessoas, [...] permanente e dialético, caracterizado por tensões, entre o que se diz ao sujeito que ele é e o que o sujeito se apropria como seu, em um movimento de identificação, não identificação e diferenciação (PLACCO; SOUZA; ALMEIDA, 2012, p. 761).

Nessa discussão sobre a importância de se considerar as especificidades, Gariglio e Burnier (2014) partem da tese de que a educação profissional seria "ofício sem saberes", na "história de uma política de não formação", necessitando de marco regulatório. Durante a pesquisa realizada, observaram que os docentes da Educação Profissional (EP) não se percebem como "professores", mas como profissionais de outras áreas que "dão aula". Também sinalizam a ausência de maior debate e empenho político, tal como pontuaram Fartes e Santos (2011).

A não percepção dos professores da EP como profissionais da educação é reforçada, num segundo nível, pela carência de estudos sobre a matéria. Acompanhando as características gerais das políticas no campo da formação de professores para o ensino técnico, pode-se afirmar, grosso modo, que estudos sobre a temática, bem como a organização dos educadores em torno de debates a respeito, vêm se desenvolvendo de forma descontínua, muito em função de momentos especiais em que essa formação é posta em questão. Assim, não tem sido construída uma cultura de produção acadêmico-científica na área (GARIGLIO; BURNIER, 2014, p. 940-941).

Já o trabalho de Barreto (2012), analisa as reformas de currículo desde 1990 com os Parâmetros Curriculares Nacionais, dentre outros, a partir do conceito de qualidade social da educação, aquela que é para todos, inclusive "os indesejáveis", põe foco no discurso da identidade do "professor reflexivo", que tem se difundido, e seus saberes advindos da experiência. De acordo com a autora, as diversas políticas e reformas de currículo no país têm influenciado na constituição dessa profissionalidade docente. Dessa forma, ressalta o poder do discurso legal como um fator para a constituição da identidade docente.

Assim, a discussão sobre a constituição da identidade profissional docente sinaliza uma 
tendência nos discursos de propor a valorização da experiência e dos saberes docentes (LÜDKE; BOING, 2012; GARIGLIO; BURNIER, 2014; BENITES; SARTI; SOUZA NETO, 2015), uso das narrativas e histórias de vida como dispositivo de formação ou metodologia de pesquisa (REALI; TANCREDI; MIZUKAMI, 2010; BEINEKE, 2012) na constituição de um profissional reflexivo e crítico. Contudo, Benites, Sarti e Souza Neto (2015) advertem sobre a importância de olhar o potencial formativo da escola com cautela.

No cenário nacional, o entusiasmo pelos slogans que colocam a escola no centro da formação docente não tem sido acompanhado pela necessária discussão sobre os dispositivos que podem fazer com que os espaços de trabalho dos professores passem a figurar como lugar de formação profissional, desconsiderando inclusive o potencial formativo dos professores experientes na iniciação das novas gerações docentes (BENITES; SARTI; SOUZA NETO, 2015, p. 103).

Por isso, reivindicam uma formação específica para o docente colaborador, experiente. Citando $\operatorname{Tardif}^{3}$ (2013 apud BENITES, SARTI; SOUZA NETO, 2015), o grande referencial teórico dos artigos analisados seria necessário avançar "da idade do ofício para a idade da profissão", para que a profissionalização do magistério aconteça.

Nesse contexto, é importante trazer para o debate o artigo de Garcia (2009) que, em sua análise, afirma que a didática propõe o uso das "tecnologias de si" ou o "cuidado de si", na acepção de Michel Foucault, como indispensável para o fazer docente. Analisa os efeitos produtivos desses discursos de caráter prescritivo, com base em uma moral pastoral e ascética. Nessa perspectiva, o sujeito docente é uma "fabricação". Cita como instrumentos desse processo as seguintes tecnologias: vivências, relatos de experiências, memórias, autorreflexão, autoconhecimento, autobiografias.

Por fim, Lopes e Borges (2015) polemizam os discursos sobre formação docente ao questionarem a necessidade de configuração de um modelo identitário de formação

\footnotetext{
${ }^{3}$ Citado diretamente em 5 artigos no período, seguido por Perrenoud, mencionado 4 vezes.
} 
profissional docente, seja ele pautado nas ideias de "tomada de consciência", "professor reflexivo", "autônomo", "competente", "emancipado" ou outras variantes, criticando a racionalidade presente nestes discursos.

[...] A ausência de certezas é nosso antídoto contra o autoritarismo e pode ser alavanca de diferentes formas de mobilização. É o antídoto contra os projetos que se afirmam como únicos, as racionalidades que desconhecem dinâmicas contextuais, os projetos que pretendem traçar diagnósticos e soluções para a formação docente pela via do cálculo ou pelas regulações intensivas, as soluções supostas como salvadoras de todos a qualquer preço (LOPES; BORGES, 2015, p. 504, grifos das autoras).

A partir de reflexões pós-estruturalistas, concluem que a diferença em relação às outras proposições discursivas estaria na recusa em defender que temos clareza do que almejamos e do modo como conseguir viabilizar esses projetos, e isto não pode dar-se fora da esfera política (LOPES; BORGES, 2015).

Desse modo, percebe-se a defesa do lugar (e portanto, capital simbólico) da escola, de relações mais horizontais e de saberes da experiência na constituição da identidade profissional do professor em suas múltiplas especificidades de atuação, bem como uma crítica aos jargões e slogans que emergem no campo.

\section{Considerações Finais}

Nesta análise, percebeu-se uma grande incidência de pesquisas de campo sobre a formação de docente, talvez como resultado discursivo em relação à proposição de políticas públicas e da produção acadêmica no cotidiano das escolas e dos professores. Também notase uma ampla utilização dos conceitos profissionalidade e saberes docentes, porém, também encontrou-se o emprego da categoria "desprofissionalização docente", como um efeito colateral da situação atual da formação docente no país, revelando uma tensão no campo da formação docente e o quanto as políticas, o currículo, e as metodologias estariam contribuindo para esta profissionalização ou desprofissionalização do magistério.

Entre 2008 e 2015, houve maior ênfase na formação continuada como estratégia para a melhoria da qualidade do ensino, principalmente dos docentes em atuação na educação 
infantil e nos anos iniciais do ensino fundamental. No entanto, com relação à formação continuada, evidenciou-se a polissemia em torno deste conceito, ou seja, há uma aposta nas modalidades mais colaborativas, coletivas, em detrimento das individuais, evidenciando o coletivo educacional das escolas e dos pares. Porém, houve uma focalização direta do coordenador pedagógico, ou outro formador, e da qualidade de suas intervenções como estratégia para a implementação da formação continuada.

Acerca da formação inicial, os discursos são propositivos no tocante à necessidade de uma aproximação real com as escolas, tanto na teorização dos saberes advindos da experiência, quanto na implementação de um estágio supervisionado que não seja apenas obrigatório e desarticulado. Nesse escopo discursivo, emerge a centralidade da escola na formação profissional, curricular e identitária dos docentes, seja na modalidade da formação continuada ou como campo na formação inicial mediante a realização do estágio supervisionado.

Nesse contexto, são necessários estudos que problematizem como a escola pode contribuir com a formação docente e desta forma, tornar este discurso mais polêmico, ou seja, oportunizando a produção de mais debates e perspectivas sob este aspecto. Há também reivindicação para que o coletivo docente deixe de ser visto como mero consumidor, para ser produtor de conhecimentos.

O grande embate discursivo do período é referente ao currículo da formação docente. Há uma cobrança em relação à metodologia e conteúdo da formação promovida pelas escolas, redes de ensino e universidades no tocante a uma aproximação com as práticas docentes, com o objetivo de promover uma emancipação educacional do coletivo docente e discente. Em contrapartida, fica a sensação que ainda "falta", seja uma concepção curricular mais articulada às demandas da escola real com a qual o professor se depara, seja uma metodologia mais dialógica entre os saberes acadêmicos e advindos da prática: algo que ainda estaria por vir. Ainda assim, os artigos trouxeram diversas experiências formativas, com diferentes vieses metodológicos e teóricos. Nesse sentido foram encontradas resistências no campo estudado, na tentativa de produção de novos saberes e metodologias formativas, questionamento dos currículos e de um "perfil" profissional único ou padrão. 
A partir da política educacional instituída pelo Plano Nacional de Educação (PNE) em 2001, esperava-se que após dez anos a qualidade da educação básica tivesse alcançado um avanço considerável, dado o grande investimento na formação docente no período. No entanto, as políticas públicas e os agentes do campo continuam focalizando a formação docente como estratégia principal para a elevação desses índices. Enfim, esta pesquisa não teve a pretensão de esgotar a análise dos temas, debates e disputas do campo da formação de professores, porém possibilitou algumas das possíveis e tendências deste período pós Década de Educação, até o ano de 2015, tendo como palco um importante periódico na área de Educação.

\section{Referências}

ANDRADE, A. Uso(s) das novas tecnologias em um programa de formação de professores: possibilidades, controle e apropriações. 2007. Dissertação (Mestrado em Educação) Universidade de São Paulo, São Paulo, 2007.

ANDRÉ, M. et al. Estado da arte da formação de professores no Brasil. Educ. Soc., Campinas, v. 20, n. 68, 1999.

BARDIN, L. Análise de Conteúdo. Lisboa. Portugal: Edições 70, 2009. 280p.

BARRETTO, E. S. S. Políticas de currículo e avaliação e políticas docentes. Cad. Pesqui., São Paulo, v. 42, n. 147, p. 738-753, dez. 2012.

BEINEKE, V. A reflexão sobre a prática na pesquisa e formação do professor de música. Cad. Pesqui., São Paulo, v. 42, n. 145, p. 180-203, abr. 2012.

BELLO, I. M. Formação superior de professores em serviço: um estudo sobre o processo de certificação do magistério no Brasil. 2008. Tese (Doutorado em Educação) - Universidade de São Paulo, São Paulo, 2008.

BELLO, I. M. Cursos e programas especiais no mercado de formação docente. In: SOUZA, D. T. R.; SARTI, F. M. (Orgs.), Mercado de Formação docente: constituição, funcionamento e dispositivos. Belo Horizonte: Fino Traço, 2014, p. 113-128.

BENITES, L. C.; SARTI, F. M.; SOUZA NETO, S. De mestres de ensino a formadores de campo no estágio supervisionado. Cad. Pesqui., São Paulo, v. 45, n. 155, p. 100-117, mar. 2015.

BOURDIEU, P. Algumas propriedades dos campos. In: (Org.), Questões de Sociologia. Rio de Janeiro: Marco Zero, 1983. p. 89-94.

Os usos sociais da ciência: por uma sociologia clínica do campo científico. Tradução Denice Bárbara Catani. São Paulo: Editora da UNESP, 2004.

BRASIL. Lei n. 9.394, de 20 de dezembro de 1996. Estabelece as Diretrizes e Bases da Educação 
Nacional. 1996. Disponível em: < http://www.planalto.gov.br/ccivil_03/leis/L9394.htm>. Acesso em: 03 mai. 2018.

MEC, 2001

Ministério de Educação e do Desporto. Plano Nacional de Educação. Brasília. DF:

Decreto Federal no 6.755, de 29 de janeiro de 2009. Institui a Política Nacional de Formação de Profissionais do Magistério da Educação Básica, disciplina a atuação da Coordenação de Aperfeiçoamento de Pessoal de Nível Superior-CAPES no fomento a programas de formação inicial e continuada, e dá outras providências. Disponível em: <http://www.planalto.gov.br/ccivil_03/_ato2007-2010/2009/decreto/d6755.htm>. Acesso em: 03 mai. 2018.

CHARRÉU, L. V.; OLIVEIRA, M. O. Diários de aula e portfólios como instrumentos metodológicos da prática educativa em artes visuais. Cad. Pesqui., São Paulo, v. 45, n. 156, p. 410-425, jun. 2015.

DAVIS, C. L. F. et al. Formação continuada de professores em alguns estados e municípios do Brasil. Cad. Pesqui., São Paulo, v. 41, n. 144, p. 826-849, dez. 2011.

FARTES, V.; SANTOS, A. P. Q. O. Saberes, identidades, autonomia na cultura docente da educação profissional e tecnológica. Cad. Pesqui., São Paulo, v. 41, n. 143, p. 376-401, ago. 2011.

GARCIA, M. M. A. Didática e trabalho ético na formação docente. Cad. Pesqui., São Paulo, v. 39 , n. 136, p. 225-242, abr. 2009.

GARCIA, P. S.; BIZZO, N. Formação contínua a distância: gestão da aprendizagem e dificuldades dos professores. Cad. Pesqui., São Paulo, v. 43, n. 149, p. 662-681, ago. 2013.

GARIGLIO, J. A.; BURNIER, S. L. Os professores da educação profissional: saberes e práticas. Cad. Pesqui., São Paulo, v. 44, n. 154, p. 934-959, dez. 2014.

GOMES, C. A.; PEREIRA, M. M. A formação do professor em face das violências das/nas escolas.

Cad. Pesqui., São Paulo, v. 39, n. 136, p. 201-224, abr. 2009.

GRIGOLI, J. A. G. et al. A escola como lócus de formação docente: uma gestão bem-sucedida.

Cad. Pesqui., São Paulo, v. 40, n. 139, p. 237-256, abr. 2010.

LOPES, A. C.; BORGES, V. Formação docente, um projeto impossível. Cad. Pesqui., São Paulo, v. 45, n. 157, p. 486-507, jul./set. 2015.

LOPONTE, L. G. Amizades: o doce sabor dos outros na docência. Cad. Pesqui., São Paulo, v. 39, n. 138, p. 919-938, dez. 2009.

LUDKE, M; BOING, L.A. Do trabalho à formação de professores. Cad. Pesqui., São Paulo, v. 42, n. 146, p. 428-451, ago. 2012.

MENDONÇA, F. L. R.; SILVA, D. N. H. A formação docente no contexto da inclusão: para uma nova metodologia. Cad. Pesqui., São Paulo, v. 45, n. 157, p. 508-526, jul./set. 2015.

PLACCO, V. M. N. S.; SOUZA, V. L. T.; ALMEIDA, L. R. O coordenador pedagógico: aportes à 
proposição de políticas públicas. Cad. Pesqui., São Paulo, v. 42, n. 147, p. 754-771, dez. 2012.

REALI, A. M. M. R.; TANCREDI, R. M. S. P.; MIZUKAMI, M. G. N. Programa de mentoria online para professores iniciantes: fases de um processo. Cad. Pesqui., São Paulo, v. 40, n. 140, p. 479-506, ago. 2010.

ROHDEN, F. Gênero, sexualidade e raça/etnia: desafios transversais na formação do professor. Cad. Pesqui., São Paulo, v. 39, n. 136, p. 157-174, abr. 2009.

SCHEIBE, L. O conselho técnico-científico da educação básica da Capes e a formação docente. Cad. Pesqui., São Paulo, v. 41, n. 144, p. 812-825, dez. 2011.

SENE, D. G. A. Rotas alternativas: histórias de professoras que não puderam cursar os Programas Especiais de Formação Pedagógica Superior em São Paulo. 2010. 180p. Dissertação (Mestrado em Educação), Universidade de São Paulo, São Paulo, 2010.

SENNA, L. A. G. Formação docente e educação inclusiva. Cad. Pesqui., São Paulo, v. 38, n. 133, p. 195-219, abr. 2008.

SILVA, O. H. F.; SOARES, A. S. Educação infantil: história e desafios contemporâneos. Argumentos Pró-Educação, Pouso Alegre, v. 2, n. 4, p. 301-320, maio-ago., 2017.

SOUSA, C. P.; BÔAS, L. P. S. V. Avaliação da formação de professores: uma perspectiva psicossocial. Cad. Pesqui., São Paulo, v. 42, n. 147, p. 772-789, dez. 2012.

\section{Apêndice 1}

Quadro 1 - Síntese das características dos estudos incluídos na análise de acordo com os autores, ano de publicação, título do artigo, categoria analítica e reflexões do artigo a partir das contribuições no campo da formação docente, publicados em Cadernos de Pesquisa 20082015.

\begin{tabular}{|l|l|l|l|}
\hline $\begin{array}{c}\text { Autores } \\
\text { (Ano de } \\
\text { publicação) }\end{array}$ & \multicolumn{1}{|c|}{ Título } & \multicolumn{1}{c|}{$\begin{array}{c}\text { Categoria } \\
\text { Analítica }\end{array}$} & $\begin{array}{l}\text { Reflexões do artigo no campo da formação } \\
\text { docente }\end{array}$ \\
\hline $\begin{array}{l}\text { Senna } \\
(2008)\end{array}$ & $\begin{array}{l}\text { Formação } \\
\text { docente e } \\
\text { educação } \\
\text { inclusiva }\end{array}$ & $\begin{array}{l}\text { O Currículo da } \\
\text { Formação } \\
\text { Docente }\end{array}$ & $\begin{array}{l}\text { Pesquisa documental. Faz crítica ao modelo de } \\
\text { formação tecnicista e ao atual, que não teria } \\
\text { rompido com uma concepção de sujeito } \\
\text { universal. Defende uma formação de } \\
\text { professores das licenciaturas para atuar junto } \\
\text { à diversidade. Propõe resgatar o ensino como } \\
\text { especialidade acadêmica a partir da reflexão } \\
\text { sobre o currículo das licenciaturas. Em seu } \\
\text { artigo, discute o fenômeno do fracasso escolar } \\
\text { e a necessidade de a escola ser inclusiva, pois } \\
\text { se percebe um estranhamento entre os novos } \\
\text { sujeitos escolares (docentes discentes). }\end{array}$ \\
\hline $\begin{array}{l}\text { Rohden } \\
\text { (2009) }\end{array}$ & $\begin{array}{l}\text { Gênero, } \\
\text { sexualidade e } \\
\text { raça/etnia: } \\
\text { desafios }\end{array}$ & $\begin{array}{l}\text { Formação } \\
\text { Docente }\end{array}$ & $\begin{array}{l}\text { Pesquisa qualitativa. Apresenta possibilidades, } \\
\text { a partir de uma experiência piloto de formação } \\
\text { continuada a distância. Discorre sobre a } \\
\text { necessidade de introduzir } \\
\text { temáticas }\end{array}$ \\
\hline
\end{tabular}




\begin{tabular}{|c|c|c|c|}
\hline & $\begin{array}{l}\text { transversais na } \\
\text { formação do } \\
\text { professor }\end{array}$ & & $\begin{array}{l}\text { referentes à diversidade no currículo da } \\
\text { formação. }\end{array}$ \\
\hline $\begin{array}{l}\text { Gomes e Pereira } \\
\text { (2009) }\end{array}$ & $\begin{array}{l}\text { A formação do } \\
\text { professor em face } \\
\text { das violências } \\
\text { das/nas escolas }\end{array}$ & $\begin{array}{l}\text { O Currículo da } \\
\text { Formação } \\
\text { Docente }\end{array}$ & $\begin{array}{l}\text { Pesquisa qualitativa com utilização de grupos } \\
\text { focais, sobre a percepção dos licenciandos a } \\
\text { respeito das violências. Crítica ao currículo e } \\
\text { metodologia dos cursos de formação e } \\
\text { continuada. Problematizam a importância do } \\
\text { estágio supervisionado para a formação } \\
\text { docente e o descaso das políticas que o } \\
\text { regulamenta. }\end{array}$ \\
\hline $\begin{array}{l}\text { Garcia } \\
(2009)\end{array}$ & $\begin{array}{l}\text { Didática e } \\
\text { trabalho ético na } \\
\text { formação } \\
\text { docente }\end{array}$ & $\begin{array}{l}\text { Formação e } \\
\text { Constituição da } \\
\text { Identidade } \\
\text { Profissional }\end{array}$ & $\begin{array}{l}\text { Pesquisa bibliográfica. Analisa os efeitos } \\
\text { produtivos desses discursos de caráter } \\
\text { prescritivo, com base em uma moral pastoral } \\
\text { e ascética. Afirma que a didática propõe o uso } \\
\text { das "tecnologias de si" ou o "cuidado de si", na } \\
\text { acepção de Michel Foucault, como } \\
\text { indispensável para o fazer docente. }\end{array}$ \\
\hline $\begin{array}{l}\text { Loponte } \\
\text { (2009) }\end{array}$ & $\begin{array}{l}\text { Amizades: o doce } \\
\text { sabor dos outros } \\
\text { na docência }\end{array}$ & $\begin{array}{l}\text { Experiências de } \\
\text { Formação } \\
\text { Docente }\end{array}$ & $\begin{array}{l}\text { Pesquisa qualitativa em que são abordadas as } \\
\text { contribuições dos saberes docentes para a } \\
\text { promoção de experiências de formação } \\
\text { diferenciadas: a primeira, não-formal, } \\
\text { desinstitucionalizada entre um grupo de } \\
\text { amigas e a segunda, ao analisar o potencial da } \\
\text { reflexão sobre a formação docente. }\end{array}$ \\
\hline $\begin{array}{l}\text { Grigoli et al. } \\
\text { (2010) }\end{array}$ & $\begin{array}{l}\text { A escola como } \\
\text { lócus de } \\
\text { formação } \\
\text { docente: uma } \\
\text { gestão bem- } \\
\text { sucedida }\end{array}$ & $\begin{array}{l}\text { Formação e } \\
\text { Constituição da } \\
\text { Identidade } \\
\text { Profissional }\end{array}$ & $\begin{array}{l}\text { Pesquisa qualitativa que destaca a importância } \\
\text { da rede de relações que se estabelece no } \\
\text { contexto da escola, como forma de } \\
\text { socialização, construção da identidade e } \\
\text { formação, defendendo a escola como lócus } \\
\text { privilegiado para a formação continuada. }\end{array}$ \\
\hline $\begin{array}{l}\text { Reali, Tancredi, } \\
\text { Mizukami } \\
(2010)\end{array}$ & $\begin{array}{l}\text { Programa de } \\
\text { mentoria online } \\
\text { para professores } \\
\text { iniciantes: fases } \\
\text { de um processo }\end{array}$ & $\begin{array}{l}\text { Experiências de } \\
\text { Formação } \\
\text { Docente }\end{array}$ & $\begin{array}{l}\text { Pesquisa-ação durante o desenvolvimento de } \\
\text { um Programa de Mentoria online pela UFSCar } \\
\text { para professores com até cinco anos de } \\
\text { exercício profissional. Reivindicam políticas } \\
\text { públicas para desenvolvimento profissional } \\
\text { docente e sugerem estratégias como o uso das } \\
\text { narrativas, casos, ações colaborativas, dentre } \\
\text { outros, defendo a escola como lócus } \\
\text { privilegiado para a formação e } \\
\text { desenvolvimento docente. }\end{array}$ \\
\hline $\begin{array}{l}\text { Scheibe } \\
\text { (2011) }\end{array}$ & $\begin{array}{l}\text { O conselho } \\
\text { técnico-científico } \\
\text { da educação } \\
\text { básica da CAPES e } \\
\text { a formação } \\
\text { docente }\end{array}$ & $\begin{array}{l}\text { Políticas } \\
\text { Públicas para a } \\
\text { Formação } \\
\text { Docente }\end{array}$ & $\begin{array}{l}\text { Pesquisa documental. Analisa o papel do } \\
\text { Conselho Técnico Científico da Educação } \\
\text { Básica da Capes, no contexto das políticas de } \\
\text { formação dos profissionais para o magistério } \\
\text { da educação básica. Pontua dificuldades tanto } \\
\text { com relação à formação inicial quanto à } \\
\text { continuada no país, devido à fragmentação } \\
\text { das políticas públicas, rebaixamento das } \\
\text { exigências de formação, rapidez da formação } \\
\text { e recursos insuficientes. }\end{array}$ \\
\hline
\end{tabular}




\begin{tabular}{|c|c|c|c|}
\hline $\begin{array}{l}\text { Davis et al. } \\
\text { (2011) }\end{array}$ & $\begin{array}{l}\text { Formação } \\
\text { continuada de } \\
\text { professores em } \\
\text { alguns estados e } \\
\text { municípios do } \\
\text { Brasil }\end{array}$ & $\begin{array}{l}\text { Políticas } \\
\text { Públicas para a } \\
\text { Formação } \\
\text { Docente } \\
\text { Experiências de } \\
\text { Formação } \\
\text { Docente }\end{array}$ & $\begin{array}{l}\text { Pesquisa qualitativa. O estudo fornece um } \\
\text { panorama das políticas de formação } \\
\text { continuada realizada em diferentes estados e } \\
\text { municípios. Concluem que é vista pela maioria } \\
\text { dos gestores educacionais como atualização } \\
\text { dos conhecimentos e habilidades para o } \\
\text { aprimoramento da profissão. Identifica } \\
\text { propostas de formação de três categorias: } \\
\text { padrão, individualizadas e colaborativas. } \\
\text { Ênfase para os saberes docentes. }\end{array}$ \\
\hline $\begin{array}{l}\text { Fartes e Santos } \\
(2011)\end{array}$ & $\begin{array}{l}\text { Saberes, } \\
\text { identidades, } \\
\text { autonomia na } \\
\text { cultura docente } \\
\text { da educação } \\
\text { profissional e } \\
\text { tecnológica }\end{array}$ & $\begin{array}{l}\text { Políticas } \\
\text { Públicas para a } \\
\text { Formação } \\
\text { Docente }\end{array}$ & $\begin{array}{l}\text { Pesquisa Bibliográfica. Explicitam que a } \\
\text { educação profissional e tecnológica pós LDB } \\
\text { (1996) vai além da ideia de ensino } \\
\text { profissionalizante. Criticam as políticas de } \\
\text { formação com o propósito de complementar a } \\
\text { formação inicial dos docentes não licenciados, } \\
\text { reivindicando uma formação específica. } \\
\text { Apresentam quatro teses desafiadoras para a } \\
\text { implementação da educação profissional e } \\
\text { técnica. }\end{array}$ \\
\hline $\begin{array}{l}\text { Beineke } \\
(2012)\end{array}$ & $\begin{array}{l}\text { A reflexão sobre a } \\
\text { prática na } \\
\text { pesquisa e } \\
\text { formação do } \\
\text { professor de } \\
\text { música }\end{array}$ & $\begin{array}{l}\text { Experiências de } \\
\text { Formação } \\
\text { Docente }\end{array}$ & $\begin{array}{l}\text { Pesquisa qualitativa com professoras de } \\
\text { música. Abordam principalmente as } \\
\text { contribuições dos saberes docentes para a } \\
\text { promoção de experiências de formação } \\
\text { diferenciada, demonstrando o potencial da } \\
\text { reflexão sobre a formação docente. Reivindica } \\
\text { políticas de formação continuada que levem } \\
\text { em consideração o ciclo profissional em que os } \\
\text { docentes se encontram. }\end{array}$ \\
\hline $\begin{array}{l}\text { Ludke e Boing } \\
\text { (2012) }\end{array}$ & $\begin{array}{l}\text { Do trabalho à } \\
\text { formação de } \\
\text { professores }\end{array}$ & $\begin{array}{l}\text { O Currículo da } \\
\text { Formação } \\
\text { Docente } \\
\text { Formação e } \\
\text { Constituição da } \\
\text { Identidade } \\
\text { Profissional }\end{array}$ & $\begin{array}{l}\text { Pesquisa bibliográfica. O estudo apresenta } \\
\text { críticas diretas às faculdades de educação. } \\
\text { Propõem que voltem-se para as práticas e } \\
\text { saberes docentes, reconduzindo-os para a } \\
\text { teorização. Citam a questão da socialização } \\
\text { profissional retroativa ao tempo em que os } \\
\text { professores eram alunos, como um fator a ser } \\
\text { levado em consideração no currículo da } \\
\text { formação docente. Crítica ao academicismo } \\
\text { das universidades e ao aligeiramento da } \\
\text { formação inicial. }\end{array}$ \\
\hline $\begin{array}{l}\text { Placco, Souza e } \\
\text { Almeida } \\
(2012)\end{array}$ & $\begin{array}{l}\text { O coordenador } \\
\text { pedagógico: } \\
\text { aportes à } \\
\text { proposição de } \\
\text { políticas públicas }\end{array}$ & $\begin{array}{l}\text { Políticas } \\
\text { Públicas para a } \\
\text { Formação } \\
\text { Docente } \\
\text { Formação e } \\
\text { Constituição da } \\
\text { Identidade } \\
\text { Profissional }\end{array}$ & $\begin{array}{l}\text { Pesquisa qualitativa. Se posicionam no campo } \\
\text { reiterando a importância do coordenador } \\
\text { pedagógico como responsável pela formação } \\
\text { continuada docente na escola, além da função } \\
\text { de articulador do Projeto Pedagógico e } \\
\text { implementador das políticas educacionais. } \\
\text { Para tanto, as autoras defendem a proposição } \\
\text { de políticas voltadas para uma formação } \\
\text { específica deste profissional (diferente da } \\
\text { formação docente), garantindo a construção } \\
\text { de sua identidade. }\end{array}$ \\
\hline
\end{tabular}




\begin{tabular}{|c|c|c|c|}
\hline $\begin{array}{l}\text { Barretto } \\
(2012)\end{array}$ & $\begin{array}{l}\text { Políticas de } \\
\text { currículo e } \\
\text { avaliação e } \\
\text { políticas docentes }\end{array}$ & $\begin{array}{l}\text { Políticas } \\
\text { Públicas para a } \\
\text { Formação } \\
\text { Docente } \\
\text { Formação e } \\
\text { Constituição da } \\
\text { Identidade } \\
\text { Profissional }\end{array}$ & $\begin{array}{l}\text { Pesquisa documental. Analisa as reformas de } \\
\text { currículo desde } 1990 \text { com os Parâmetros } \\
\text { Curriculares Nacionais, dentre outros, a partir } \\
\text { do conceito de qualidade social da educação. } \\
\text { Discute como as políticas curriculares (ciclo, } \\
\text { avaliação etc.) interferem na constituição da } \\
\text { profissionalidade docente. Identifica o } \\
\text { discurso da identidade do "professor } \\
\text { reflexivo", que tem se difundido, e seus } \\
\text { saberes advindos da experiência, na } \\
\text { constituição de uma outra profissionalidade } \\
\text { docente. }\end{array}$ \\
\hline $\begin{array}{l}\text { Souza e Bôas } \\
(2012)\end{array}$ & $\begin{array}{l}\text { Avaliação da } \\
\text { formação de } \\
\text { professores: uma } \\
\text { perspectiva } \\
\text { psicossocial }\end{array}$ & $\begin{array}{l}\text { Políticas } \\
\text { Públicas para a } \\
\text { Formação } \\
\text { Docente }\end{array}$ & $\begin{array}{l}\text { Pesquisa bibliográfica. Apresenta } \\
\text { alguns dilemas em torno de como avaliar a } \\
\text { qualidade da formação inicial e de docentes já } \\
\text { em exercício. Discorre sobre as possibilidades } \\
\text { e limitações do ENADE (com o uso de provas } \\
\text { padronizadas para avaliar a qualidade da } \\
\text { formação inicial) e do uso das avaliações como } \\
\text { o SAEB e a Prova Brasil para avaliar o } \\
\text { desempenho de docentes em exercício, bem } \\
\text { como orientar a elaboração de políticas } \\
\text { públicas. }\end{array}$ \\
\hline $\begin{array}{l}\text { Garcia e Bizzo } \\
(2013)\end{array}$ & $\begin{array}{l}\text { Formação } \\
\text { contínua a } \\
\text { distância: gestão } \\
\text { da aprendizagem } \\
\text { e dificuldades dos } \\
\text { professores }\end{array}$ & $\begin{array}{l}\text { Políticas } \\
\text { Públicas para a } \\
\text { Formação } \\
\text { Docente } \\
\text { Experiências de } \\
\text { Formação } \\
\text { Docente }\end{array}$ & $\begin{array}{l}\text { Pesquisa qualitativa. Discorrem sobre um } \\
\text { programa de formação contínua para } \\
\text { professores de Ciências, que busca contribuir } \\
\text { para o planejamento de novas atividades para } \\
\text { a educação a distância de docentes em } \\
\text { exercício. Ao mapearem mecanismos de } \\
\text { estudo, aprendizagem e dificuldades desse } \\
\text { grupo, têm como objetivo contribuir para a } \\
\text { proposição de cursos mais atrativos e } \\
\text { eficientes, bem como podem minimizar as } \\
\text { desistências ao longo do processo. }\end{array}$ \\
\hline $\begin{array}{l}\text { Gariglio e } \\
\text { Burnier } \\
(2014)\end{array}$ & $\begin{array}{l}\text { Os professores da } \\
\text { educação } \\
\text { profissional: } \\
\text { saberes e práticas }\end{array}$ & $\begin{array}{l}\text { Políticas } \\
\text { Públicas para a } \\
\text { Formação } \\
\text { Docente } \\
\text { Formação e } \\
\text { Constituição da } \\
\text { Identidade } \\
\text { Profissional }\end{array}$ & $\begin{array}{l}\text { Pesquisa qualitativa. Partem da tese de que a } \\
\text { educação profissional seria "ofício sem } \\
\text { saberes", na "história de uma política de não } \\
\text { formação", necessitando de marco } \\
\text { regulatório. Durante a pesquisa realizada, } \\
\text { observaram que os docentes da Educação } \\
\text { Profissional - EP não se percebem como } \\
\text { "professores", mas como profissionais de } \\
\text { outra área que dão aula, bem como a ausência } \\
\text { de maior debate e empenho político para } \\
\text { contribuir com a formação deste professor. }\end{array}$ \\
\hline $\begin{array}{l}\text { Benites, Sarti, } \\
\text { Souza Neto } \\
(2015)\end{array}$ & $\begin{array}{l}\text { De mestres de } \\
\text { ensino a } \\
\text { formadores de } \\
\text { campo no estágio } \\
\text { supervisionado }\end{array}$ & $\begin{array}{l}\text { Políticas } \\
\text { Públicas para a } \\
\text { Formação } \\
\text { Docente }\end{array}$ & $\begin{array}{l}\text { Pesquisa bibliográfica. Trazem uma } \\
\text { inquietação acerca da forma como o estágio } \\
\text { supervisionado nas licenciaturas tem se } \\
\text { concretizado, como "mera complementação } \\
\text { da formação acadêmica, perdendo sua }\end{array}$ \\
\hline
\end{tabular}




\begin{tabular}{|c|c|c|c|}
\hline & & $\begin{array}{l}\text { Formação e } \\
\text { Constituição da } \\
\text { Identidade } \\
\text { Profissional } \\
\end{array}$ & $\begin{array}{l}\text { especificidade como oportunidade de } \\
\text { aproximação do trabalho docente e espaço de } \\
\text { iniciação à docência", caracterizando-se por } \\
\text { certa espontaneidade e improvisação. }\end{array}$ \\
\hline $\begin{array}{l}\text { Lopes e Borges } \\
\text { (2015) }\end{array}$ & $\begin{array}{l}\text { Formação } \\
\text { docente, um } \\
\text { projeto } \\
\text { impossível }\end{array}$ & $\begin{array}{l}\text { Políticas } \\
\text { Públicas para a } \\
\text { Formação } \\
\text { Docente } \\
\text { O Currículo da } \\
\text { Formação } \\
\text { Docente }\end{array}$ & $\begin{array}{l}\text { Pesquisa bibliográfica. A formação docente é } \\
\text { apresentada como um projeto impossível, } \\
\text { necessário e que precisa se perceber como } \\
\text { imprevisível para poder avançar. Propõem a } \\
\text { ousadia de se admitir os embates políticos } \\
\text { entre as diferentes perspectivas de } \\
\text { estabilização do discurso sobre a formação }\end{array}$ \\
\hline $\begin{array}{l}\text { Mendonça e } \\
\text { Silva (2015) }\end{array}$ & $\begin{array}{l}\text { A formação } \\
\text { docente no } \\
\text { contexto da } \\
\text { inclusão: para } \\
\text { uma nova } \\
\text { metodologia }\end{array}$ & $\begin{array}{l}\text { O Currículo da } \\
\text { Formação } \\
\text { Docente } \\
\text { Experiências de } \\
\text { Formação } \\
\text { Docente }\end{array}$ & $\begin{array}{l}\text { Estudo teórico. Aposta na formação } \\
\text { continuada e enfatiza a necessidade de a } \\
\text { escola colaborar para a construção de uma } \\
\text { sociedade em que as diferenças identitárias e } \\
\text { as deficiências não sejam vistas como } \\
\text { desvantagens ou patologias, defendendo uma } \\
\text { política de inclusão, uma vez que a exclusão } \\
\text { consiste na negação da diversidade. Os } \\
\text { autores apostam na formação continuada, } \\
\text { com a problematização da prática docente a } \\
\text { partir do conceito de "clínica da atividade". }\end{array}$ \\
\hline $\begin{array}{l}\text { Charréu e } \\
\text { Oliveira } \\
(2015)\end{array}$ & $\begin{array}{l}\text { Diários de aula e } \\
\text { portfólios como } \\
\text { instrumentos } \\
\text { metodológicos da } \\
\text { prática educativa } \\
\text { em artes visuais }\end{array}$ & $\begin{array}{l}\text { Experiências de } \\
\text { Formação } \\
\text { Docente } \\
\text { Formação e } \\
\text { Constituição da } \\
\text { Identidade } \\
\text { Profissional }\end{array}$ & $\begin{array}{l}\text { Parte de um relato de prática que teve os } \\
\text { diários de aula e portfólios como material para } \\
\text { formação docente e avança para um estudo } \\
\text { teórico destes recursos. Propõem que o uso } \\
\text { dessa metodologia visa qualificar o trabalho } \\
\text { do professor e possibilita uma reflexão sobre a } \\
\text { sua própria prática, o que, no entanto, } \\
\text { também pode ser usado pelo seu formador, na } \\
\text { universidade ou na escola. }\end{array}$ \\
\hline
\end{tabular}

Fonte: Os autores.

Recebido em: 11/11/2017

Aprovado em: 03/05/2018 